\begin{abstract}
Aims: To evaluate the association of fetal fraction on cell-free DNA (cfDNA) testing with first trimester markers for pre-eclampsia and to investigate a possible association of low fetal fraction with increased risk for pre-eclampsia (PE) and fetal growth restriction (FGR).
\end{abstract}

Methods: This was a retrospective cohort study including all women with singleton pregnancies who had risk calculation for PE and FGR between 11+0 and $13+6$ weeks' gestation and also decided to have cfDNA as a primary or secondary screening test for chromosomal abnormalities at any gestational age in two Fetal Medicine clinics in Sydney and Melbourne, Australia, between March 2013 and May 2017. Logarithmically transformed fetal fraction results were adjusted for gestational age and maternal characteristics. Associations with mean arterial pressure (MAP), mean uterine artery pulsatility index (UtAPI), pregnancy-associated plasma protein A (PAPP-A), placental growth factor (PIGF) and risks for pre-eclampsia before 34 and 37 weeks' gestation and fetal growth restriction before 37 weeks' gestation were analyzed through correlation analysis and univariate and multivariate linear regression.

Results: In total, 4,317 singleton pregnancies subjected to cfDNA testing with reported fetal fraction were included. Significant prediction of fetal fraction was provided by gestational age, in vitro fertilization, maternal age, BMI, chronic hypertension, diabetes mellitus and South Asian ethnicity and multiparity without previous history of PE or FGR. Fetal fraction was inversely associated with MAP and UtAPI and positively associated with PAPP-A and PIGF. The lower the fetal fraction, the higher was the risk for $P E<34$ weeks, $P E<37$ weeks and FGR $<37$ weeks $(p<0.001)$.

Conclusion: There is a significant association between fetal fraction results and first trimester markers for adverse pregnancy outcome. Low fetal fraction is associated with an increased risk for pregnancy complications, but its capacity

This is the author manuscript accepted for publication and has undergone full peer review but has not been through the copyediting, typesetting, pagination and proofreading process, which may lead to differences between this version and the Version of Record. Please cite this article as doi: 10.1002/uog.18993

This article is protected by copyright. All rights reserved. 
to act an as independent first trimester marker in an algorithm screening for PE and FGR requires further research.

This article is protected by copyright. All rights reserved. 


\section{Introduction}

In the 1990's, Lo et al. described the presence of cell-free DNA (cfDNA) in the maternal circulation and reported that the concentrations of fetal DNA were increased in the plasma of women carrying fetuses with trisomy $21^{1,} 2$. Screening for chromosomal abnormalities based on cell-free fetal DNA has become clinically available since 2011 given its high accuracy for the detection of trisomy 21 both in high-risk and general populations ${ }^{3-5}$.

The accuracy of the test depends on the proportion of the total cfDNA that contains fetal genetic material (fetal fraction), being higher when the fetal fraction is high and performing poorly when the fetal fraction is low ${ }^{6}$. While not all laboratories offering cfDNA test measure fetal fraction, some companies do not provide a result if the fetal fraction is below $4 \%$. Previous studies show that fetal fraction increases with advancing gestational age, decreases in pregnancies conceived by in vitro fertilization (IVF) and in women with increased body mass index (BMI) and can vary according to ethnic origin ${ }^{7-9}$.

Since cell-free 'fetal' DNA actually originates from the developing placenta ${ }^{10}$, studies have suggested that the release of cell-free fetal DNA would be related to the size of the placenta and to the rate of trophoblastic apoptosis $^{11}$, therefore cfDNA and fetal fraction measurements could potentially be used as a screening test for placental disorders such as pre-eclampsia (PE) and fetal growth restriction (FGR).

There has been an increasing interest in screening for PE in the first trimester, particularly since the publication of recent meta-analyses ${ }^{12,13}$ and a large randomized controlled trial showing that aspirin intake initiated before 16 weeks' gestation is effective in reducing the prevalence of preterm cases of $\mathrm{PE}^{14}$. Although various studies show an increase in both fetal and total cfDNA in the maternal circulation in women already diagnosed with $P E^{15-19}$, little is known regarding fetal fraction in these cases and whether its measurement could be 
used as a marker of placental dysfunction in asymptomatic women ${ }^{20}$. Since recent studies have shown a positive linear correlation of fetal fraction with other biochemical markers of placental function ${ }^{21}$, women at increased risk for placental disorders would be more likely to have reduced fetal fraction on cfDNA testing ${ }^{22}$ or to receive a failed result report. The literature on the possible association of fetal fraction with predictive markers and risk for developing PE in the general population is scarce.

The aim of this study is to evaluate if fetal fraction on cfDNA testing is associated with first trimester biophysical and biochemical markers for PE, as well as to investigate a possible association of low fetal fraction with increased risk for $P E$ and FGR. 


\section{Materials and Methods}

\section{Study population}

This was a retrospective cohort study including all women with singleton pregnancies who had first trimester risk calculation for PE and FGR between 11 and 13+6 weeks' gestation who also had cfDNA as a primary or secondary screening test for fetal chromosomal abnormalities, at any gestational age, in two private Fetal Medicine clinics in Sydney and Melbourne, Australia.

Only cases between March 2013 and May 2017 with reported fetal fraction were included. Multiple pregnancies and cases with uninformative results were excluded from analysis.

\section{Procedure and data collection}

Each participating ultrasound practice has a well-established program of first trimester combined screening for fetal chromosomal abnormalities comprising fetal structural assessment, nuchal translucency measurement and biomarkers (free beta human chorionic gonadotropin [ß-hCG], pregnancy-associated plasma protein A [PAPP-A] and placental growth factor [PIGF]). All patients who opted to have this test as first-tier screening were also offered risk calculation for PE at the same time.

Women who opted to have cfDNA testing as the primary screening method before 11 weeks' gestation had an ultrasound examination prior to blood sampling in order to confirm pregnancy viability and exclude multiple pregnancy and were advised to return for fetal structural assessment between 11 and 13+6 weeks' gestation. In all cases, gestational age was calculated based on the fetal crown-rump length $(\mathrm{CRL})$ at 11 to $13+6$ weeks' gestation.

Maternal demographic characteristics were recorded, as well as medical, obstetric and family history. Mean arterial pressure (MAP) was calculated following a previously published technique ${ }^{23}$, using the average of two 
measurements in each arm. Both left and right uterine arteries pulsatility indices were measured following a standardized technique ${ }^{24}$ and the mean value (UtAPI) was recorded. The individual risks for FGR requiring delivery before 37 weeks of gestational age and for PE requiring delivery before 34 and 37 weeks of gestational age were calculated using the Fetal Medicine Foundation (FMF) algorithm ${ }^{25}$, combining maternal factors, MAP and UtAPI for all cases and also PAPP-A and PIGF when biochemistry results were available. All markers were expressed in multiples of the median (MoM) after adjustment for gestational age and maternal characteristics.

Blood samples for cfDNA testing (Harmony ${ }^{\circledR}$, Roche/Ariosa Diagnostics Inc., San Jose, California, United States of America [USA]) were analyzed in the USA (Ariosa Diagnostics, California) or in Australia (Douglass Hanly Moir, Queensland) as previously described ${ }^{26-28}$. In samples with a fetal fraction less than $4 \%$, the laboratory did not report fetal fraction or generate a cfDNA risk assessment.

As this was a clinical audit of a validated screening program that did not identify patients directly and did not seek pregnancy outcome information, patient consent was not required. The study involved de-identified data for analysis and quality assurance purposes, thus ethical clearance was not required as per the National Health and Medical Research Council (NHMRC) 2014 Ethical Considerations in Quality Assurance and Evaluation Activities ${ }^{29}$.

\section{Statistical analysis}

Baseline characteristics of the population were expressed in absolute values and percentages for categorical variables and medians and interquartile ranges (IQR) for continuous variables. Fetal fraction distribution was made Gaussian with logarithmic transformation and linear regression analysis was performed in order to identify which of the maternal characteristics affect $\log _{10}$ fetal fraction values. The results were then adjusted for gestational age and maternal 
characteristics and expressed as multiples of the median $\left(\log _{10}\right.$ fetal fraction MoM).

First trimester markers for pre-eclampsia (MAP, UtAPI, PAPP-A and PIGF) were also expressed in MoM and transformed to the logarithmic scale. To compensate for the potential effect of missing values for MAP, UtAPI and risks (missing completely at random, < 5\%) linear regression-based sensitivity analysis was conducted using a multiple imputed strategy $(M=10)$ and pooled results were used.

The associations between fetal fraction and markers and risks for PE and FGR were evaluated with Pearson correlation analysis and with univariate and multivariate truncated linear regression analysis (as fetal fraction values of less than $4 \%$ were not included in the dataset). These associations were represented in scatter plot charts with lines of best fit from truncated regression and Lowess mean estimation lines.

Finally, separate analyses were performed for the groups with and without biochemistry in order to assess possible differences between these two groups that could introduce bias. Statistical analysis was performed using the software Stata ${ }^{\circledR}$ (version 14.1, StataCorp, Texas, USA). 


\section{Results}

A total of 4317 singleton pregnancies with first trimester screening for PE and cfDNA results with reported fetal fraction were included. Of those, $2252(51.9 \%)$ had screening for PE with all four markers included and 2065 (48.1\%) had PE risk calculation without biochemical markers. Baseline characteristics of the population are shown in Table 1.

Gestational age had a significant positive association with fetal fraction. Of the maternal factors, conception by IVF, increased maternal age, increased BMI, chronic hypertension, type 1 or type 2 diabetes mellitus and South Asian ethnicity were significantly associated with reduced fetal fraction. Multiparity without previous history of PE or FGR was significantly associated with higher fetal fraction values.

In the univariate analysis, both MAP and UtAPI showed a significant inverse association with fetal fraction $(r=-.118, p<0.001$ and $r=-.064, p<$ 0.001 for MAP and UtAPI, respectively - Figure 1 and Table 2), and this association was maintained in a multivariate analysis including only these two markers.

PAPP-A and PIGF had a significant positive association with fetal fraction $(r=.219, p<0.001$ and $r=.091, p<0.001$ for PAPP-A and PIGF, respectively - Figure 2 and Table 2).

Consequently, there was also a significant negative correlation between fetal fraction and risks for PE before 34 and 37 weeks' gestation and risk for FGR ( $r=-.199, r=-.199$ and $r=-.102$, respectively; all $p<0.001$ - Figure 3). Using a risk cut-off of 1 in 100 for PE before 37 weeks' gestation, the median fetal fraction in the high-risk group was 10.4\% (IQR 7.8, 13.2), compared to $11.8 \%$ (IQR 9.2, 14.8) in the low-risk group $(p<0.001)$.

In the multivariate analysis (including only cases with all four markers measured), however, the association of UtAPI and PIGF with fetal fraction did 
not remain independently significant after addition of PAPP-A to the model (Table 2).

There were no significant differences in baseline characteristics and the results of the linear regression were similar in the groups with and without biochemistry, suggesting that the coefficients would be similar if all the cases included had results of PAPP-A and PIGF. 


\section{Discussion}

\section{Main findings}

The findings that MAP and UtAPI are negatively associated and that PAPP-A and PIGF are positively associated with fetal fraction reinforce the hypothesis that lower fetal fraction may be a consequence of smaller placental mass and even an early sign of placental dysfunction. This study, to the best of our knowledge, is the first to analyze a possible correlation between fetal fraction and biophysical markers for PE. The results suggest that women at increased risk for PE and FGR tend to have lower fetal fraction, which is in keeping with findings previously reported by Norton et al. in a large study comparing women who developed PE to those that did not ${ }^{22}$.

Previous studies have reported increased quantities of both total and fetal cfDNA in the circulation of women diagnosed with $P E^{16-19}$, markedly in those with severe $P E^{30}$. These findings have been attributed to accelerated apoptosis of trophoblastic cells as a result of placental ischemia, inflammatory nature of the vascular and end-organ damage and reduced clearance of cfDNA from the maternal circulation in cases of placental dysfunction ${ }^{31}$. The apparently discrepant results (lower fetal fraction as opposed to increase in absolute quantities of fetal cfDNA) may be due to a less pronounced increase in fetal cfDNA compared to maternal cfDNA, with a consequent reduction in fetal fraction.

Few studies have evaluated the potential use of cfDNA measurements as a screening test for PE in asymptomatic women. Recent systematic reviews were unable to draw definite conclusions as to its potential predictive value ${ }^{17,32}$. In a case-control study, Rolnik et al. demonstrated that in patients with earlyonset PE the total and the fetal cfDNA are increased and the fetal fraction is reduced, but such associations were not seen after adjustment for maternal characteristics that affect these measurements ${ }^{33}$. 
Scott et al. have also demonstrated a significant positive association of biochemical markers and fetal fraction on cfDNA test ${ }^{21}$. In our analysis, however, the association of PIGF and UtAPI with fetal fraction did not remain significant in the multivariate linear regression when all markers were included in the model. This is possibly due to the strong association of PAPP-A with fetal fraction and to the fact that there is some degree of overlapping between different first trimester markers, with lower values of UtAPI and higher values of PLGF associated with higher PAPP-A results.

\section{Clinical implications and study limitations}

The findings of this study support the hypothesis that low fetal fraction is associated with a higher risk of developing PE or FGR, as there is a clear association between fetal fraction and first trimester markers, and consequently with the individual risk for development of these conditions. Cases with less than $4 \%$ fetal fraction were not included in this study, but it would be reasonable to expect a higher chance of uninformative results due to low fetal fraction among patients at high-risk for PE and FGR. Accordingly, Chan et al. reported a significantly higher rate of pre-eclampsia among patients who had uninformative results due to low fetal fraction compared to the general obstetric population ${ }^{34}$.

It is unclear whether the addition of fetal fraction to a multi-marker screening test would increase the accuracy of the test, as the effect of this parameter in the risk calculation may not be clinically significant and independent once other markers that show an association with fetal fraction are also included in the multiple regression model. Further research on this topic is needed to investigate this hypothesis.

Moreover, although our results suggest that this would be the case, it is crucial to identify if patients that indeed developed preterm PE or FGR have lower fetal fraction when compared to uncomplicated pregnancies. If so, fetal fraction could potentially enhance first trimester screening for PE, particularly in 
cases where placental biochemistry was not performed. The fact that the outcomes of the pregnancies were not collected is one of the main limitations of this study, and this is now being addressed in a large pregnancy outcome study from both units.

Another limitation of this study was the fact that half of the analyzed cohort did not have results for PAPP-A and PIGF. However, the number of pregnancies analyzed was large, the number of cases with biochemistry included was also considerable, and a separate analysis including pregnancies with and without biochemistry results showed no significant differences between the groups, which is reassuring.

\section{Conclusions}

Low fetal fraction on cfDNA testing may be a marker of poor placental development and placental dysfunction, as there is a significant correlation with first trimester markers for PE and risk for PE and FGR. Nonetheless, the possible benefit of using fetal fraction to improve current predictive models is unclear and merits further research. 


\section{References}

1. Lo YM, Corbetta N, Chamberlain PF, Rai V, Sargent IL, Redman CW, Wainscoat JS. Presence of fetal DNA in maternal plasma and serum. Lancet 1997; 350: 485-487. DOI 10.1016/S0140-6736(97)02174-0.

2. Lo YM, Lau TK, Zhang J, Leung TN, Chang AM, Hjelm NM, Elmes RS, Bianchi DW. Increased fetal DNA concentrations in the plasma of pregnant women carrying fetuses with trisomy 21. Clin Chem 1999; 45: 1747-1751.

3. Gil MM, Accurti V, Santacruz B, Plana MN, Nicolaides KH. Analysis of cellfree DNA in maternal blood in screening for aneuploidies: updated meta-analysis. Ultrasound Obstet Gynecol 2017. DOI 10.1002/uog.17484.

4. American College of Obstetricians and Gynecologists Committee on Genetics. Committee Opinion No. 545: Noninvasive prenatal testing for fetal aneuploidy. Obstet Gynecol 2012; 120: 1532-1534. DOI 10.1097/01.AOG.0000423819.85283.f4.

5. Salomon LJ, Alfirevic Z, Audibert F, Kagan KO, Paladini D, Yeo G, RaineFenning N, Committee ICS. ISUOG updated consensus statement on the impact of cfDNA aneuploidy testing on screening policies and prenatal ultrasound practice. Ultrasound Obstet Gynecol 2017; 49: 815-816. DOI 10.1002/uog.17483.

6. Wright D, Wright A, Nicolaides KH. A unified approach to risk assessment for fetal aneuploidies. Ultrasound Obstet Gynecol 2015; 45: 48-54. DOI 10.1002/uog.14694.

7. Ashoor G, Poon L, Syngelaki A, Mosimann B, Nicolaides KH. Fetal fraction in maternal plasma cell-free DNA at 11-13 weeks' gestation: effect of maternal and fetal factors. Fetal Diagn Ther 2012; 31: 237-243. DOI 10.1159/000337373.

8. Ashoor G, Syngelaki A, Poon LC, Rezende JC, Nicolaides KH. Fetal fraction in maternal plasma cell-free DNA at 11-13 weeks' gestation: relation to maternal and fetal characteristics. Ultrasound Obstet Gynecol 2013; 41: 26-32. DOI 10.1002/uog.12331.

9. Revello R, Sarno L, Ispas A, Akolekar R, Nicolaides KH. Screening for trisomies by cell-free DNA testing of maternal blood: consequences of a failed result. Ultrasound Obstet Gynecol 2016; 47: 698-704. DOI 10.1002/uog.15851.

10. Flori E, Doray B, Gautier E, Kohler M, Ernault P, Flori J, Costa JM. Circulating cell-free fetal DNA in maternal serum appears to originate from cyto- and syncytiotrophoblastic cells. Case report. Hum Reprod 2004; 19: 723-724. DOI 10.1093/humrep/deh117.

11. Wataganara T, Metzenbauer M, Peter I, Johnson KL, Bianchi DW. Placental volume, as measured by 3-dimensional sonography and levels of maternal plasma cellfree fetal DNA. Am $J$ Obstet Gynecol 2005; 193: 496-500. DOI 10.1016/j.ajog.2004.12.015.

12. Roberge S, Nicolaides K, Demers S, Hyett J, Chaillet N, Bujold E. The role of aspirin dose on the prevention of preeclampsia and fetal growth restriction: systematic review and meta-analysis. Am J Obstet Gynecol 2017; 216: 110-120 e116. DOI 10.1016/j.ajog.2016.09.076.

13. Roberge S, Villa P, Nicolaides K, Giguere Y, Vainio M, Bakthi A, Ebrashy A, Bujold E. Early administration of low-dose aspirin for the prevention of preterm and 
term preeclampsia: a systematic review and meta-analysis. Fetal Diagn Ther 2012; 31: 141-146. DOI 10.1159/000336662.

14. Rolnik DL, Wright D, Poon LC, O'Gorman N, Syngelaki A, de Paco Matallana C, Akolekar R, Cicero S, Janga D, Singh M, Molina FS, Persico N, Jani JC, Plasencia W, Papaioannou G, Tenenbaum-Gavish K, Meiri H, Gizurarson S, Maclagan K, Nicolaides KH. Aspirin versus Placebo in Pregnancies at High Risk for Preterm Preeclampsia. N Engl J Med 2017; 377: 613-622. DOI 10.1056/NEJMoa1704559.

15. Alberry MS, Maddocks DG, Hadi MA, Metawi H, Hunt LP, Abdel-Fattah SA, Avent ND, Soothill PW. Quantification of cell free fetal DNA in maternal plasma in normal pregnancies and in pregnancies with placental dysfunction. Am J Obstet Gynecol 2009; 200: 98 e91-96. DOI 10.1016/j.ajog.2008.07.063.

16. Caramelli E, Rizzo N, Concu M, Simonazzi G, Carinci P, Bondavalli C, Bovicelli L, Farina A. Cell-free fetal DNA concentration in plasma of patients with abnormal uterine artery Doppler waveform and intrauterine growth restriction--a pilot study. Prenat Diagn 2003; 23: 367-371. DOI 10.1002/pd.596.

17. Contro E, Bernabini D, Farina A. Cell-Free Fetal DNA for the Prediction of PreEclampsia at the First and Second Trimesters: A Systematic Review and Meta-Analysis. Mol Diagn Ther 2017; 21: 125-135. DOI 10.1007/s40291-016-0245-9.

18. Farina A, Sekizawa A, Iwasaki M, Matsuoka R, Ichizuka K, Okai T. Total cellfree DNA (beta-globin gene) distribution in maternal plasma at the second trimester: a new prospective for preeclampsia screening. Prenat Diagn 2004; 24: 722-726. DOI 10.1002/pd.973.

19. Lo YM, Leung TN, Tein MS, Sargent IL, Zhang J, Lau TK, Haines CJ, Redman CW. Quantitative abnormalities of fetal DNA in maternal serum in preeclampsia. Clin Chem 1999; 45: 184-188.

20. Kim SY, Kim HJ, Park SY, Han YJ, Choi JS, Ryu HM. Early Prediction of Hypertensive Disorders of Pregnancy Using Cell-Free Fetal DNA, Cell-Free Total DNA, and Biochemical Markers. Fetal Diagn Ther 2016; 40: 255-262. DOI $10.1159 / 000444524$.

21. Scott FP, Menezes M, Palma-Dias R, Nisbet D, Schluter P, da Silva Costa F, McLennan AC. Factors affecting cell-free DNA fetal fraction and the consequences for test accuracy. J Matern Fetal Neonatal Med 2017: 1-8. DOI 10.1080/14767058.2017.1330881.

22. Norton M, Musci T, Wapner R. 358: Relationship between 1st trimester fetal fraction of cell-free DNA from maternal plasma and preeclampsia in a large general pregnancy population. American Journal of Obstetrics \& Gynecology; 212: S188. DOI 10.1016/j.ajog.2014.10.404.

23. Poon LC, Kametas NA, Pandeva I, Valencia C, Nicolaides KH. Mean arterial pressure at $11(+0)$ to $13(+6)$ weeks in the prediction of preeclampsia. Hypertension 2008; 51: 1027-1033. DOI 10.1161/HYPERTENSIONAHA.107.104646. 
24. Plasencia W, Maiz N, Bonino S, Kaihura C, Nicolaides KH. Uterine artery Doppler at $11+0$ to $13+6$ weeks in the prediction of pre-eclampsia. Ultrasound Obstet Gynecol 2007; 30: 742-749. DOI 10.1002/uog.5157.

25. Poon LC, Kametas NA, Maiz N, Akolekar R, Nicolaides KH. First-trimester prediction of hypertensive disorders in pregnancy. Hypertension 2009; 53: 812-818. DOI 10.1161/HYPERTENSIONAHA.108.127977.

26. Juneau K, Bogard PE, Huang S, Mohseni M, Wang ET, Ryvkin P, Kingsley C, Struble CA, Oliphant A, Zahn JM. Microarray-based cell-free DNA analysis improves noninvasive prenatal testing. Fetal Diagn Ther 2014; 36: 282-286. DOI $10.1159 / 000367626$.

27. Sparks AB, Struble CA, Wang ET, Song K, Oliphant A. Noninvasive prenatal detection and selective analysis of cell-free DNA obtained from maternal blood: evaluation for trisomy 21 and trisomy 18. Am J Obstet Gynecol 2012; 206: 319 e311319. DOI 10.1016/j.ajog.2012.01.030.

28. Sparks AB, Wang ET, Struble CA, Barrett W, Stokowski R, McBride C, Zahn J, Lee K, Shen N, Doshi J, Sun M, Garrison J, Sandler J, Hollemon D, Pattee P, TomitaMitchell A, Mitchell M, Stuelpnagel J, Song K, Oliphant A. Selective analysis of cellfree DNA in maternal blood for evaluation of fetal trisomy. Prenat Diagn 2012; 32: 3-9. DOI 10.1002/pd.2922.

29. NHRMC: Ethical Considerations in Quality Assurance and Evaluation Activities, 2014. $\quad$ https://www.nhmrc.gov.au/guidelines-publications/e111 $\quad$ [22 September 2017].

30. Miranda ML, Macher HC, Munoz-Hernandez R, Vallejo-Vaz A, Moreno-Luna R, Villar J, Guerrero JM, Stiefel P. Role of circulating cell-free DNA levels in patients with severe preeclampsia and HELLP syndrome. Am J Hypertens 2013; 26: 1377-1380. DOI 10.1093/ajh/hpt187.

31. Lau TW, Leung TN, Chan LY, Lau TK, Chan KC, Tam WH, Lo YM. Fetal DNA clearance from maternal plasma is impaired in preeclampsia. Clin Chem 2002; 48 : 2141-2146.

32. Martin A, Krishna I, Badell M, Samuel A. Can the quantity of cell-free fetal DNA predict preeclampsia: a systematic review. Prenat Diagn 2014; 34: 685-691. DOI 10.1002/pd.4416.

33. Rolnik DL, O'Gorman N, Fiolna M, van den Boom D, Nicolaides KH, Poon LC. Maternal plasma cell-free DNA in the prediction of pre-eclampsia. Ultrasound Obstet Gynecol 2015; 45: 106-111. DOI 10.1002/uog.14671.

34. Chan N, Smet ME, Sandow R, da Silva Costa F, McLennan A. Implications of failure to achieve a result from prenatal maternal serum cell-free DNA testing: a historical cohort study. BJOG 2017. DOI 10.1111/1471-0528.15006. 
Figure legends:

Figure 1. Bivariable scatterplots of logarithmically transformed fetal fraction MoM values against mean arterial pressure $\left(\log _{10} \mathrm{MoM}\right)$ and mean uterine artery pulsatility index $\left(\log _{10} \mathrm{MoM}\right)$, with superimposed Lowess curves (dash) and lines of best fit from truncated regression (solid).

$r=-.118, p<0.001$ for MAP; $r=-.064, p<0.001$ for UtAPI.

Figure 2. Bivariable scatterplots of logarithmically transformed fetal fraction MoM values against pregnancy-associate plasma protein-A $\left(\log _{10} M o M\right)$ and placental growth factor $\left(\log _{10}\right.$ MoM), with superimposed Lowess curves (dash) and lines of best fit from truncated regression (solid).

$r=.219, p<0.001$ for PAPP-A; $r=.091, p<0.001$ for PIGF

Figure 3. Bivariable scatterplots of logarithmically transformed fetal fraction MoM values against the logarithmically transformed inverse risks of delivering a baby with a) fetal growth restriction before 37 weeks, b) pre-eclampsia before 34 weeks or c) pre-eclampsia before 37 weeks, with superimposed Lowess curves (dash) and lines of best fit from truncated regression (solid).

$r=-.102, p<0.001$ for FGR before 37 weeks

$r=-.199, p<0.001$ for PE before 34 weeks

$r=-.199, p<0.001$ for PE before 37 weeks 
Table 1. Baseline characteristics of the study population.

\begin{tabular}{lc}
\hline Maternal age, median (IQR) & $34.8(31.7,37.9)$ \\
GA at cfDNA test, median (IQR) & $11.0(10.4,11.7)$ \\
GA at PE screening, median (IQR) & $12.9(12.5,13.3)$ \\
Ethnicity & \\
Caucasian & $3245(75.2)$ \\
Afro-Caribbean & $4(0.1)$ \\
$\quad$ South Asian & $231(5.3)$ \\
East Asian & $721(16.7)$ \\
Mixed & $116(2.7)$ \\
Parity $\quad$ & \\
Nullip & $2429(56.2)$ \\
Multip & $1889(43.8)$ \\
$\quad$ with previous PE & $65 / 1889(5.5)$ \\
$\quad$ with previous FGR & $30 / 1889(2.5)$ \\
Conception & \\
Spontaneous & $3643(84.4)$ \\
Ovulation drugs & $25(0.6)$ \\
IVF & $649(15.0)$ \\
Smoking & $59(1.4)$ \\
Diabetes mellitus & \\
Type 1 & $13(0.3)$ \\
Type 2 & $13(0.3)$ \\
SLE $\quad 33(0.8)$ \\
\hline
\end{tabular}




\begin{tabular}{lc}
\hline APS & $10(0.2)$ \\
Family history of PE (mother) & $110(2.5)$ \\
\hline
\end{tabular}

Data are presented in median (IQR) or $\mathrm{n}(\%)$.

IQR, Interquartile range; GA, Gestational age; cfDNA, cell-free DNA test; PE, pre-eclampsia; FGR, fetal growth restriction; IVF, in vitro fertilization; SLE, systemic lupus erythematosus; APS, antiphospholipid syndrome.

Table 2. Truncated regression coefficients for the association between first trimester markers for pre-eclampsia and $\log _{10}$ fetal fraction on univariate ( $n=4317$ for MAP and UtAPI and $n=2252$ for PAPP-A and PIGF) and multivariate $(n=2252)$ analyses.

\begin{tabular}{lcccc}
\hline & \multicolumn{1}{c}{ Univariate } & Multivariate \\
& Coefficient $(95 \% \mathrm{Cl})$ & $\mathrm{p}$ & Coefficient $(95 \% \mathrm{Cl})$ & $\mathrm{p}$ \\
\hline $\log _{10}$ MAP MoM & $-0.339(-0.448,-0.229)$ & $<0.001$ & $-0.295(-0.447,-0.144)$ & $<0.001$ \\
Log $_{10}$ UtAPI MoM & $-0.084(-0.120,-0.048)$ & $<0.001$ & $-0.033(-0.084,0.017)$ & 0.202 \\
$\log _{10}$ PAPP-A MoM & $0.150(0.127,0.174)$ & $<0.001$ & $0.149(0.121,0.176)$ & $<0.001$ \\
$\log _{10}$ PIGF MoM & $0.080(0.045,0.115)$ & $<0.001$ & $0.006(-0.004,0.017)$ & 0.240 \\
\hline
\end{tabular}

MAP, mean arterial pressure; MoM, multiples of the median; UtAPI, mean uterine artery pulsatility index; PAPP-A, pregnancy-associated plasma protein-A; PIGF, placental growth factor

This article is protected by copyright. All rights reserved. 

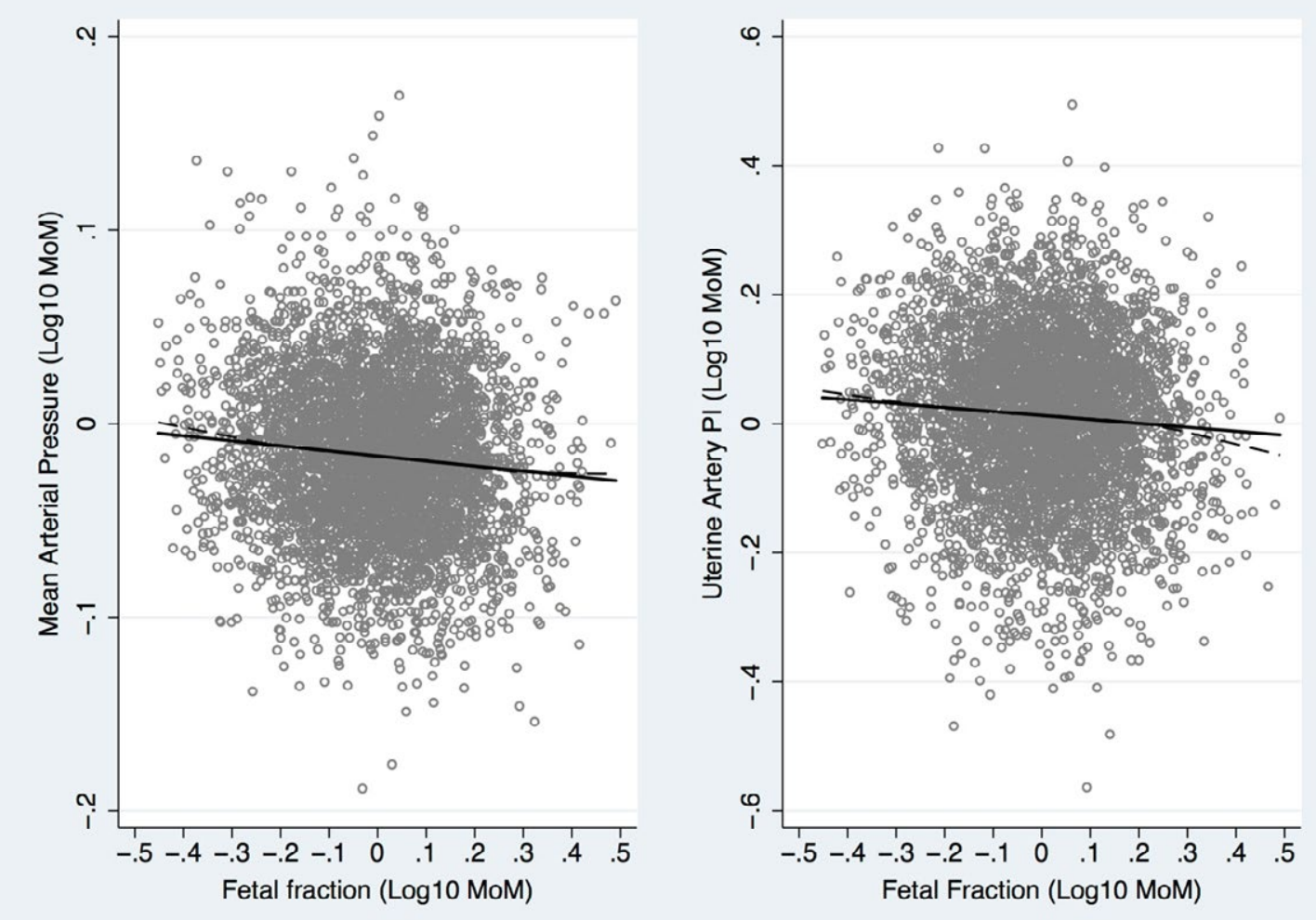

Figure 1. Bivariable scatterplots of logarithmically transformed fetal fraction MoM values against mean arterial pressure $\left(\log _{10} \mathrm{MoM}\right)$ and mean uterine artery pulsatility index $\left(\log _{10} \mathrm{MoM}\right)$, with superimposed Lowess curves (dash) and lines of best fit from truncated regression (solid).

$r=-.118, p<0.001$ for MAP; $r=-.064, p<0.001$ for UtAPI.

This article is protected by copyright. All rights reserved. 

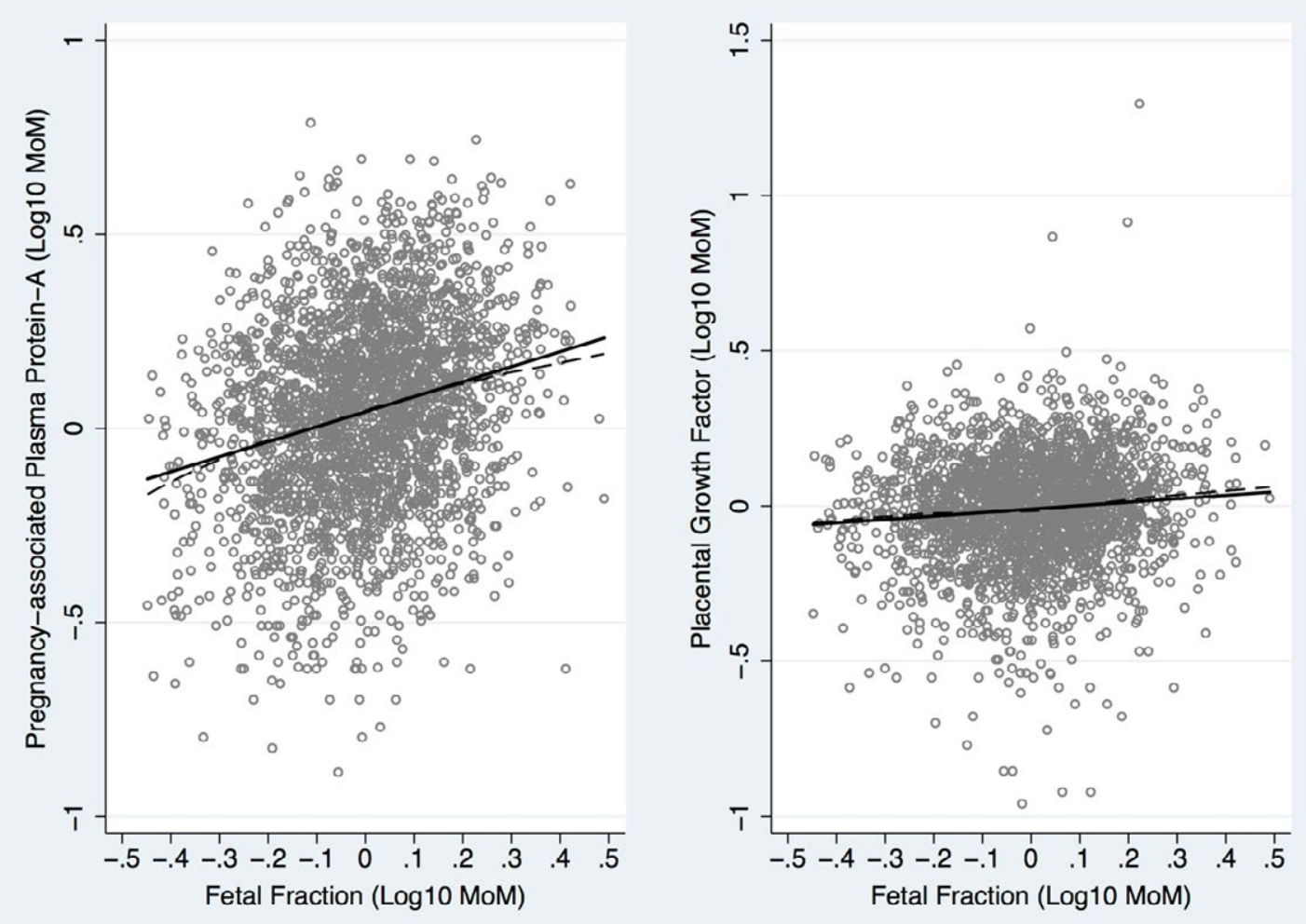

Figure 2. Bivariable scatterplots of logarithmically transformed fetal fraction MoM values against pregnancy-associate plasma protein-A $\left(\log _{10} \mathrm{MoM}\right)$ and placental growth factor $\left(\log _{10} \mathrm{MoM}\right)$, with superimposed Lowess curves (dash) and lines of best fit from truncated regression (solid). $r=.219, p<0.001$ for PAPP-A; $r=.091, p<0.001$ for PIGF 
a

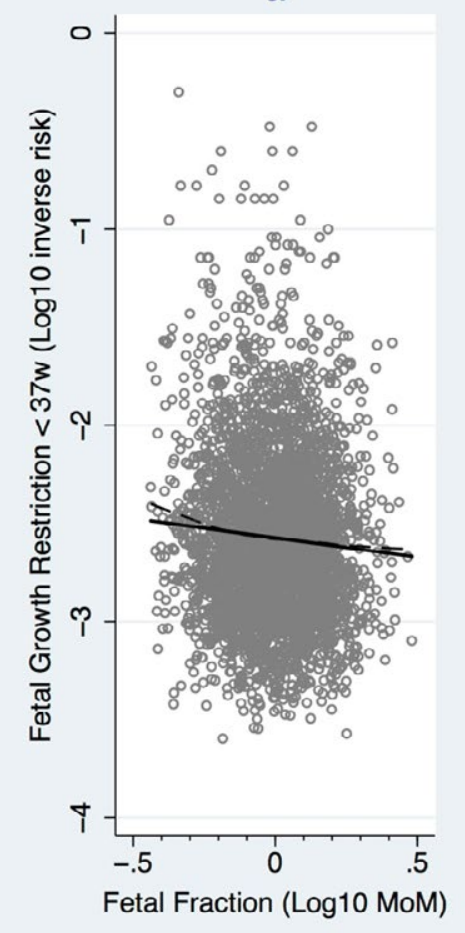

b

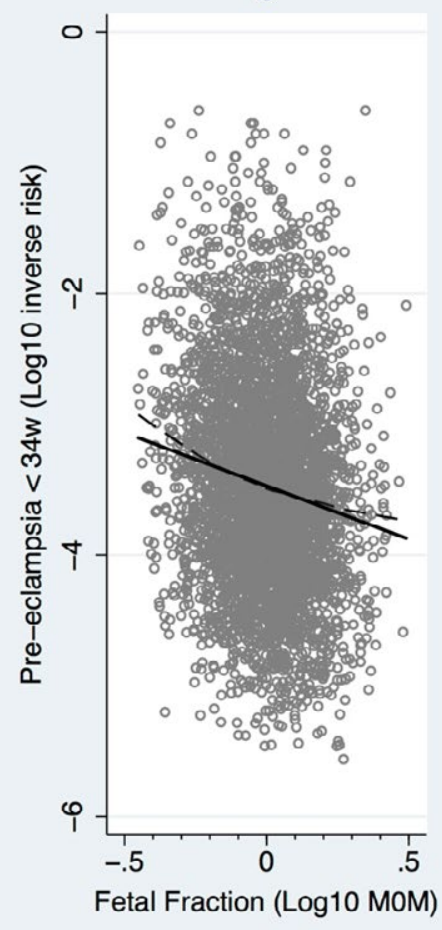

C

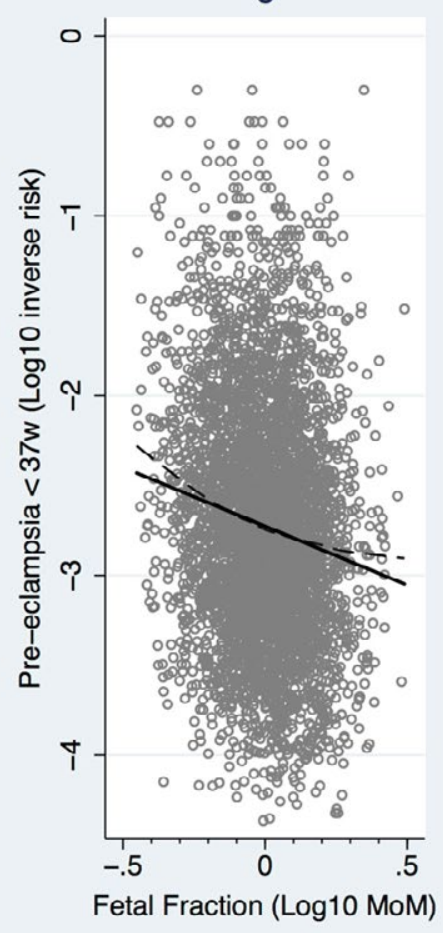

Figure 3. Bivariable scatterplots of logarithmically transformed fetal fraction MoM values against the logarithmically transformed inverse risks of delivering a baby with a) fetal growth restriction before 37 weeks, b) pre-eclampsia before 34 weeks or c) pre-eclampsia before 37 weeks, with superimposed Lowess curves (dash) and lines of best fit from truncated regression (solid).

$r=-.102, p<0.001$ for FGR before 37 weeks

$r=-.199, p<0.001$ for PE before 34 weeks

$r=-.199, p<0.001$ for PE before 37 weeks 


\title{
Association between fetal fraction on cell-free DNA testing and first trimester markers for pre-eclampsia
}

\author{
Daniel L. Rolnik ${ }^{1,2}$, Fabricio da Silva Costa ${ }^{2,3}$, Timothy J. Lee ${ }^{3}$, \\ Maximilian Schmid ${ }^{4}$, Andrew C. McLennan ${ }^{5,6}$
}

1. Perinatal Services, Monash Medical Centre, Clayton, Victoria, Australia

2. Department of Obstetrics and Gynaecology, Monash University, Clayton, Victoria, Australia

3. Monash Ultrasound for Women, Clayton, Victoria, Australia

4. Roche Sequencing Solutions, San Jose, CA, United States of America

5. Discipline of Obstetrics, Gynaecology and Neonatology, University of Sydney, New South Wales, Australia

6. Sydney Ultrasound for Women, Sydney, New South Wales, Australia

Corresponding author:

Dr Daniel L Rolnik

Department of Obstetrics and Gynaecology, Monash University

246 Clayton Road, Clayton VIC 3168, Australia

daniel.rolnik@nhs.net

Short title: First trimester markers for pre-eclampsia and cfDNA fetal fraction.

Key words: Pre-eclampsia First trimester, Biomarkers, Cell-Free DNA, Fetal fraction, Screening

Conflicts of interest: M. Schmid is an employee of Ariosa Diagnostics Inc., Roche Sequencing Solutions Inc. 


\section{University Library}

\section{- M M I N E R VA A gateway to Melbourne's research publications}

Minerva Access is the Institutional Repository of The University of Melbourne

Author/s:

Rolnik, DL;da Silva Costa, F;Lee, TJ;Schmid, M;McLennan, AC

Title:

Association between fetal fraction on cell-free DNA testing and first-trimester markers for pre-eclampsia.

Date:

2018-12

Citation:

Rolnik, D. L., da Silva Costa, F., Lee, T. J., Schmid, M. \& McLennan, A. C. (2018).

Association between fetal fraction on cell-free DNA testing and first-trimester markers for pre-eclampsia.. Ultrasound Obstet Gynecol, 52 (6), pp.722-727. https://doi.org/10.1002/ uog.18993.

Persistent Link:

http://hdl.handle.net/11343/284718 